\title{
Academic Continuity: Staying True to Teaching Values and Objectives in the Face of Course Interruptions
}

\author{
ABSTRACT
}

Academic continuity planning is an emerging tool for dealing with class cancellation associated with natural disasters, acts of violence and the threat of pandemics. However, academic continuity can also be an issue with respect to less dramatic events, such as power outages, inclement weather, or the temporary unavailability of an instructor, especially if the problem is recurring. Many of the proposed alternative forms of delivery involve some form of web-based learning, but the extent to which these approaches work when students expect face-to-face delivery has not previously been examined. In one such interruption, web-based conferencing from home was undertaken. Based on average test scores, learning was unimpeded by web-based conferencing for one week, but there were some small gender effects that warrant further investigation. Many student comments reflected reduced engagement. The professor noted that students were more likely to respond to questions when the students could see the professor instead of the slides, but in general there were fewer student responses to questions than in face-to-face lectures. A number of comments made unsolicited comparisons with the traditional lecture format, suggesting that the context for teaching and learning, and students' previous experience of different teaching approaches may merit more discussion in online learning studies.

\section{KEYWORDS}

class cancellation, gender, natural disasters, pandemics, Skype, student engagement, violence, web-based conferencing

\section{INTRODUCTION}

Occasional class cancellations are not uncommon events on college and university campuses. Inclement weather, professor sickness or competing commitments are often the cause. Student reaction to cancelled classes has traditionally been one of celebration rather than regret (Lu and Ramsey, 2013). However, values are changing. Cancelled classes have become problematic for many students, especially in the context of high tuition fees and the widely held view of students as consumers (Nielsen, 2011). Class cancellation can be inconvenient to students and the professor's expectations of how students should 
deal with class cancellations are often unclear (Berschbank, 2010). It is now widely recognized that students deserve better than to find a note on a lecture room door stating the lecture is cancelled. Timely and convenient notice of class cancellations is now readily available via mobile technology in many institutions (Buultjens and Robinson, 2011; Brouwer and McDonnell, 2009).

Other issues associated with class cancellations have also emerged in recent years. Externally accredited programs require a certain number of instructional hours, and class cancellations require missed instruction to be made up in some way (Leonard, 2009). Cancelled guest lectures can be particularly problematic because they are provided by experts with unique expertise, requiring substitution of not just the lecturer, but also the topic (Quesada-Pineda, Adams, \& Hammett, 2011). The number of cancelled lectures may also be a performance indicator and can reflect badly on an institution (McKimm, 2008).

The traditional, perhaps rather casual view of class cancellation is also challenged by recent events. Natural disasters, acts of violence, and the threat of pandemics have pushed university and college administrators to be more aware of the need to maintain appropriate learning environments when conventional face-to-face teaching and learning is impossible. The result is a growing interest in academic continuity planning (SchWeber, 2013). Many institutions have established academic continuity plans and toolkits to cover emergency situations. Virginia Tech, the University of Washington Law School, and the University of British Columbia are a few examples of institutions that have online academic continuity plans. Commercial organizations, such as Desire2Learn, are interested in associated market opportunities for technology mediated learning products (e.g., Douglas, 2011).

Response to catastrophic events is not just hypothetical. In response to Hurricane Katrina in 2005 and related events, universities in New Orleans adopted mobile devices and made available a range of online courses, including some provided by other institutions (Foster and Young, 2005; Omar et al 2008, SchWeber, 2008), and students in a war zone in Lebanon were provided with lectures on DVDs (SchWeber, 2008).

Class cancellation may be attributed to unplanned events, but it has also been advised for pandemic influenza (Santibañez, 2009). However, the efficacy of class cancellation is uncertain, since there are so many potential virus sources (Holmes et al., 2011). Plans for academic continuity during inter-pandemic periods, including online teaching and assessment, have been recognized as important but are rarely delivered (Van, McLaws, Crimmins, MacIntyre, \& Seale, 2010). One reported exception occurred at Northern Virginia Community College, which in 2009 instigated a training program for professors to shift their courses to an online environment in the event of an influenza outbreak (Young, 2009).

Clearly, there are many forms of disruption to academic continuity, and these can be differentiated in terms of their spatio-temporal context (figure 1). However, instructor absence, campus closures, and regional disruptions all have in common the fact that they prevent the coming together of students and instructor in the classroom, they disrupt academic continuity, are usually unplanned, and are of uncertain duration.

Despite the growing interest in academic continuity plans, there is little research on the impacts of online learning due to class cancellation (Meyer and Wilson, 2011). An- 


\section{SPATIAL EXTENT}

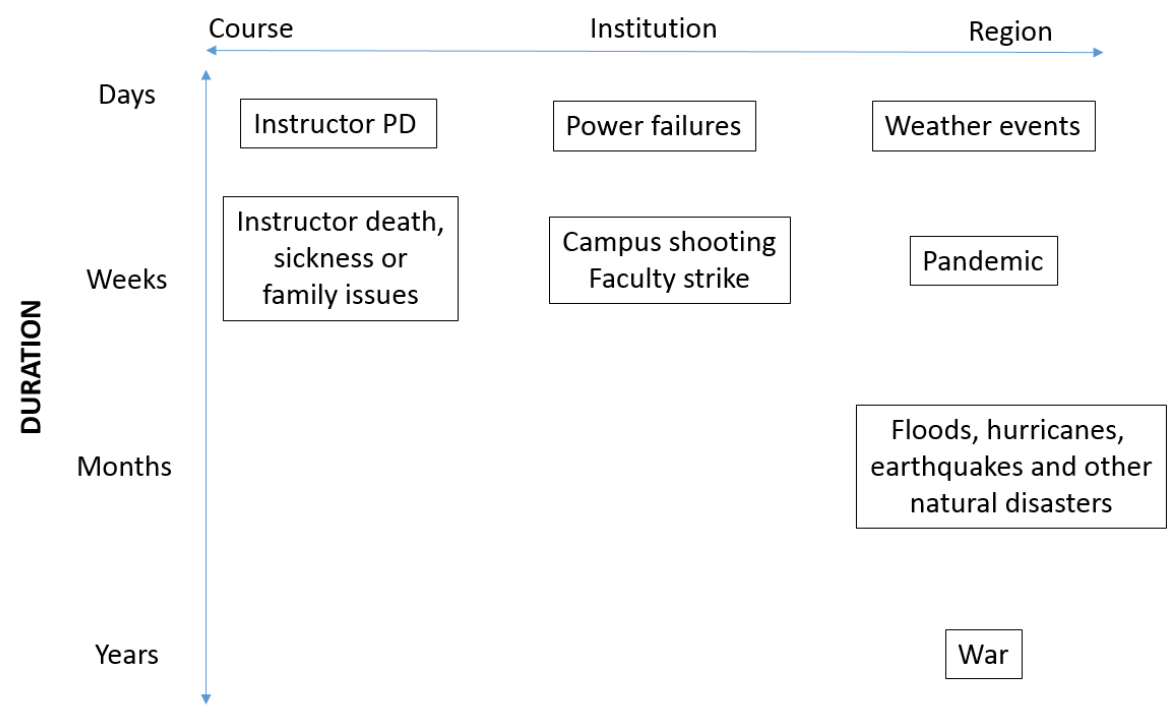

Figure 1: Spatio-temporal relationships of academic continuity issues. For events of considerable spatial and temporal extent there is a greater degree of uncertainty with respect to return to normalcy. This is particularly the case for war, with numerous issues surviving and emerging even after the (unpredictable) cessation of hostilities.

ecdotal evidence from Valley City State University in North Dakota suggests many professors struggled to adapt their courses to an online environment during a flood (Young, 2009). However, there remains a gap in studies that systematically examine the implementation and effectiveness of learning under unplanned conditions.

This paper describes the results of an attempt to address the one-week absence of a professor from the classroom due to a personal situation that made it essential for the professor to be at home and not on campus for a one-week period in January 2012. As such, it represents the low end of the spectrum of unplanned events (figure 1). Although it was an option to cancel classes for one week, the use of web-based conferencing from home was elected. The results of this teaching are examined with test scores, examination answers, student comments, and reflections from the professor.

Although the work reported here relates specifically to instructor absence for a short time, the experience provides an opportunity to explore and test one of many possible approaches to academic continuity under shorter and less stressful conditions than would be experienced in a pandemic or major natural disaster. The extent to which web-based technologies work for a short time when students expect face-to-face delivery has not previously been examined. As such, the study marks the first time that the effects of an approach to academic continuity on student learning has been documented. These results are supplemented by discussion of the challenges faced by the instructor, with implications of the experience for academic continuity planning in the context of more serious disruption. 


\section{THE TEACHING AND LEARNING CONTEXT}

Okanagan College is a multi-campus community college in British Columbia, Canada that offers applied degree and university transfer courses, together with technology, trades, vocational and foundation programs. The courses taught were two introductory undergraduate courses in physical geography and a second-year course in geographical hydrology. All courses consisted of lectures and labs. The lectures used PowerPoint slides, but the lectures themselves were interactive with continuous two-way flows of questions and answers. My lecturing style is fairly animated and I often make use of humour. I like to make lectures interesting and to develop and maintain good rapport with students.

Introductory physical geography at Okanagan College is taught in two separate courses, each of which lasts for one semester (approximately 13 weeks), with 3 hours of lectures and 3 hours of labs per week. Both classes use a just-in-time approach (Higdon and Topaz, 2009), with weekly readings and student responses to questions on areas of difficulty and special interest. Weekly responses are worth 10 percent of the grade. There are also weekly quizzes worth 15 percent, labs (10 percent), a mid-term exam (20 percent), a lab test ( 15 percent) and a final examination ( 30 percent).

Typical students are local 19-year-old high school graduates, together with mature students in their late 20 s and 30s. There were very few international students. The female:male ratio is approximately $2: 1$.

Both the introductory physical geography courses and the second-year course in geographical hydrology can be used for university transfer credit. Class sizes were in the range of sixteen to twenty-eight students.

\section{BACKGROUND OF THE PROFESSOR}

My experience with educational technology was limited to learning platforms such as Moodle and Blackboard, which I regularly use for posting lecture slides and student assignments. I have no experience teaching an online course. However, I have taken an online Certificate in Distance Education through Indiana University and obtained a masters degree in geographical information science through online study. I also participated in webinars delivered with technologies such as Elluminate.

Okanagan College has an educational technology office that provides training to faculty in a wide range of educational technologies. Although I have not taken their courses or workshops, I have sought and readily obtained their advice when needed.

\section{OPTIONS CONSIDERED}

Following consultation with the Educational Technology Office, several approaches were considered. The options were to cancel classes, provide an assignment such as a reading or exercise, locate an appropriate video to show in class or in student's own time, find a substitute professor, or to use some form of e-learning technology.

Cancelation of the class would have been acceptable to the college administration, and would have been the easiest solution. It was not the best teaching solution, however. I am committed to teaching and learning, and it didn't feel "right" to me. I had a joint obligation to my family and students. Finding a substitute professor was another good option as we occasionally cover classes for each other. In this case, there was a need to cover 9 hours of lectures. I feel this was too much to ask. 
Asynchronous learning was also considered as a possibility. Students wouldn't have had to come to class but could log in to the course management system at whatever time suited them during the week. This could have been an online discussion forum, the creation of wiki pages about particular topics of interest, or some other form of assignment. However, one of my main tasks as a college professor is to inspire and interest students, and an additional unplanned assignment in an already planned schedule seemed more punitive than inspirational. Alternatively, students could watch a video recording of a lecture on YouTube, TeacherTube, or similar service. I previously appeared in a two-part video explanation of topographic map profiles. Although comments on the video have generally been favourable and the first part of the video has been viewed some 35,000 times, the second part of the video has been viewed much less than part one. The combined length of the videos is less than 12 minutes. I was not confident that student interest could be maintained for the equivalent of nearly 3 hours for each course. With respect to videos produced by others, I have been unable to locate videos that cover what I think the students need to know at an appropriate level. My experience has been that educational videos are boring for most students, as evidenced by a lack of student attention during video presentations, sometimes to the extent of falling asleep in class.

Synchronous e-learning is the closest option to face-to-face instruction, and has the advantage of maintaining academic continuity for students. However, it does pose technological challenges for the novice user. My primary interest was that whatever approach I took would work for students and felt comfortable to me.

After considering the pros and cons of such options as Adobe Flash Media Live Encoder and Elluminate, we ultimately chose Skype. Skype was familiar and simple to operate at both ends. One of the advantages was the screen-share function that enabled me to share my computer screen and also for students to see me through the webcam. It was also possible for me to see the students. The main disadvantage was that the students had to be in close proximity to a microphone to be heard.

\section{METHODS}

Students in the three courses were informed the week prior of the professor's need for web-based conferencing and the reason why. Teaching attempted to replicate the face-toface experience as much as possible. A high resolution camera/microphone was used by the professor with a single camera/microphone in the classroom. The screen share function in Skype was used to project slides onto the classroom screen with interludes of the professor being visible and speaking directly to the class. The intent was to be as interactive as possible and questions were asked of students as the lecture proceeded, but fewer than in a regular face-to-face class. Every Skype lecture occurred in the same room and on the same schedule as face-to-face lectures. The college Educational Technology Coordinator was present during the lecture to ensure the technology worked successfully. There were delays of a few minutes at the start of every class whilst the equipment was set up.

The courses I teach always include weekly quizzes and that made evaluation of the implementation straightforward. In the first-year classes, the quizzes consist of 10 multiplechoice questions that relate to material covered in the previous week. In the second-year class, the quiz consisted of five short answer questions. For quizzes in all classes, there were one or two bonus questions that required an answer in the form of a paragraph or diagram. Normally these are administered on paper in class, and once the students have 
it completed, we review the answers together. For the week I was away, quizzes were administered by the Educational Technology Coordinator (who is also a faculty member), but answers were not reviewed at the end of the quiz.

Upon my return to the college, I marked the quizzes. Comparisons were subsequently made between weekly test scores after the week of web-based conferencing and scores obtained in previous and subsequent weeks after face-to-face lectures. In the introductory classes, many test questions were recycled, and so for one of the introductory courses, comparisons were also made with quiz scores obtained in an identical quiz in a previous year. In the week following the web-based conferencing, students answered a weekly quiz bonus question that invited reflection on their experience with web-based conferencing. Analysis of the comments was subsequently shared with the students. Reflective questions of this type are occasional features in all regular classes I teach.

Student learning was also evaluated through answers to identical questions in the final examinations of GEOG 111 and 121. The number of correct and incorrect answers from the Winter 2012 class were compared with answers from the previous and subsequent offering of the courses. These summative evaluations are not returned to students, so none of the questions were compromised.

\section{RESULTS}

Students were divided on their opinion of whether the approach worked (Table 1). Of the 61 students who reflected on their learning, 6 students unequivocally disliked the approach, 21 students unequivocally liked it, and 34 students were ambivalent. The ambivalent students thought it worked, but had some reservations, or preferred face-to-face lectures. Most of the 32 female students were ambivalent (22), but more of the 29 male students liked (13) or disliked (4) the Skype lectures.

Common sources of student concern included difficulty in focusing or concentrating during the lecture ( 9 students), which in some cases was related to student noise in the classroom (4 students). Other common issues were related and included the relatively low level of student-professor interaction ( 9 students), and the importance of the physical presence of the professor (9 students), especially with respect to the use of body movement to convey enthusiasm and explanations during the lecture. Occasional concerns were also expressed about the technology, such as not wishing to appear on camera, feeling intimidated by the professor's "giant face" on the screen, and the physical discomfort of watching an elevated screen. Student suggestions for improvement included more microphones to enable the professor to better hear students, a better sound system in the classroom, better screen positioning to avoid neck strain, and clearer PowerPoint slides.

Technical issues noted by students, myself, and the Educational Technology Coordinator included the clarity of slides on the screen, difficulty hearing student responses to questions, and delays in the start of the lecture due to technical issues. I noted that students were more likely to respond to questions when the students could see me instead of the slides. However, in general it was observed that responses were fewer than in face-to-face lectures.

With respect to learning measured by test results, a comparison was made between weekly quiz scores obtained following the Skype lectures and weekly quiz scores from the previous and following week in the first-year weather and climate course and second-year hydrology course (Table 2). For the first-year course, the average score after the Skype lec- 
Table 1: Selected student comments

\begin{tabular}{|c|c|}
\hline Students who liked it (21) & $\begin{array}{l}\text { • "Very good hands on experience from a ways away. Able to under- } \\
\text { stand as clear as if you were actually in the class." } \\
\text { • "I thought they were high tech (awesome) and really had the same ef- } \\
\text { fect as a normal stand-up lecture." } \\
\text { • "... worked very well. I appreciate the fact that Skype was used rather } \\
\text { than cancelling the class..." } \\
\text { • "It was good, not too much different from normal." } \\
\text { - "Skype lectures were basically the same as regular lectures, worked } \\
\text { well." }\end{array}$ \\
\hline Students who didn't like it (6) & $\begin{array}{l}\text { - "I felt like I was being stared at by a giant face." } \\
\text { - "I found the Skype lectures harder to follow and difficult for you to } \\
\text { interact with students and get the point across, and people were not } \\
\text { asking questions." } \\
\text { - "I found it hard to pay attention in the Skype classes and I felt they } \\
\text { were much less interactive." } \\
\text { - “... hard to concentrate." } \\
\text { - “... I found it very impersonal" }\end{array}$ \\
\hline Ambivalent (34) & $\begin{array}{l}\text { - "Personally the Skype lectures were fine and I did not mind them. } \\
\text { However, that isn't to say that I would like more." } \\
\text { " "The Skype lectures worked fairly well. I would have preferred you } \\
\text { to be in class so you could explain things a little better and so I could } \\
\text { talk with you after." } \\
\text { - "I found it a little harder to take notes when you were on Skype. But it } \\
\text { wasn't too bad. Also a little harder to focus. Don't leave us!" } \\
\text { " “. . better than I expected , but people talking at full volume in the } \\
\text { back of the room made it hard to concentrate." } \\
\text { " We missed you." }\end{array}$ \\
\hline
\end{tabular}

tures was $6.58 / 10$, slightly lower than the $6.83 / 10$ for the quiz in the face-to-face previous and subsequent week. On the basis of an unpaired two-tailed t-test. This difference is nonsignificant (Table 2). For the second-year course, the average after the Skype lectures was $5.63 / 10$ versus $5.89 / 10$ for the quizzes in the face-to-face previous and subsequent week. This difference was also non-significant. It was not possible to undertake a full analysis of the weekly test scores for the first-year water and landforms course because the timing of weekly tests was changed after the post-Skype test, in response to student requests.

The results reported here show no overall significant difference between face-to-face and web-based conferencing lectures over one week in two courses. Neither is there a difference by gender when the data are combined (Table 2). However, an examination of paired data based on a smaller dataset of students who took the test after the Skype lectures together with the tests in the weeks before and after shows a slightly different story (Figure 2). Most female students scored the same or lower in the weekly quiz based on the Skype lecture than they did with face-to-face lectures. In contrast, almost all the male students scored the same or higher after the Skype lecture than after the face-to-face lecture. 
Table 2: Comparison of quiz scores

GEOG 111 WINTER 2012:

PREVIOUS/

TWO-TAILED P VALUE 0.6413

SKYPED LECTURE

SUBSEQUENT TESTS

\begin{tabular}{lcc} 
Mean & 6.580 & 6.827 \\
\hline SD & 1.706 & 2.355 \\
\hline SEM & 0.341 & 0.327 \\
\hline $\mathbf{N}$ & 25 & 52 \\
\hline
\end{tabular}

GEOG/EESC 205 WINTER 2012:

PREVIOUS/

TWO-TAILED P VALUE 0.7623

SKYPED LECTURE

SUBSEQUENT TESTS

\begin{tabular}{lcc} 
Mean & 5.632 & 5.886 \\
\hline $\mathbf{S D}$ & 2.748 & 3.027 \\
\hline $\mathbf{S E M}$ & 0.630 & 0.512 \\
\hline $\mathbf{N}$ & 19 & 35 \\
\hline
\end{tabular}

PREVIOUS/

GEOG 1112011-2012:

SUBSEQUENT COURSE

TWO-TAILED P VALUE 0.0581

SKYPED LECTURE SECTIONS

\begin{tabular}{lcc} 
Mean & 6.580 & 5.767 \\
\hline SD & 1.706 & 1.782 \\
\hline SEM & 0.341 & 0.235 \\
\hline $\mathbf{N}$ & 25 & 58 \\
\hline
\end{tabular}

FEMALE STUDENTS

PREVIOUS/

TWO-TAILED P VALUE 0.6523

SKYPED LECTURE SUBSEQUENT TESTS

\begin{tabular}{lcc} 
Mean & 6.66 & 6.937 \\
\hline SD & 2.120 & 2.578 \\
\hline SEM & 0.424 & 0.365 \\
\hline $\mathbf{N}$ & 25 & 50 \\
\hline
\end{tabular}

MALE STUDENTS

PREVIOUS/

TWO-TAILED P VALUE $\mathbf{0 . 6 1 3 0}$

SKYPED LECTURE SUBSEQUENT TESTS

\begin{tabular}{lcc} 
Mean & 6.211 & 5.847 \\
\hline SD & 2.213 & 2.661 \\
\hline SEM & 0.508 & 0.444 \\
\hline $\mathbf{N}$ & 19 & 36 \\
\hline
\end{tabular}




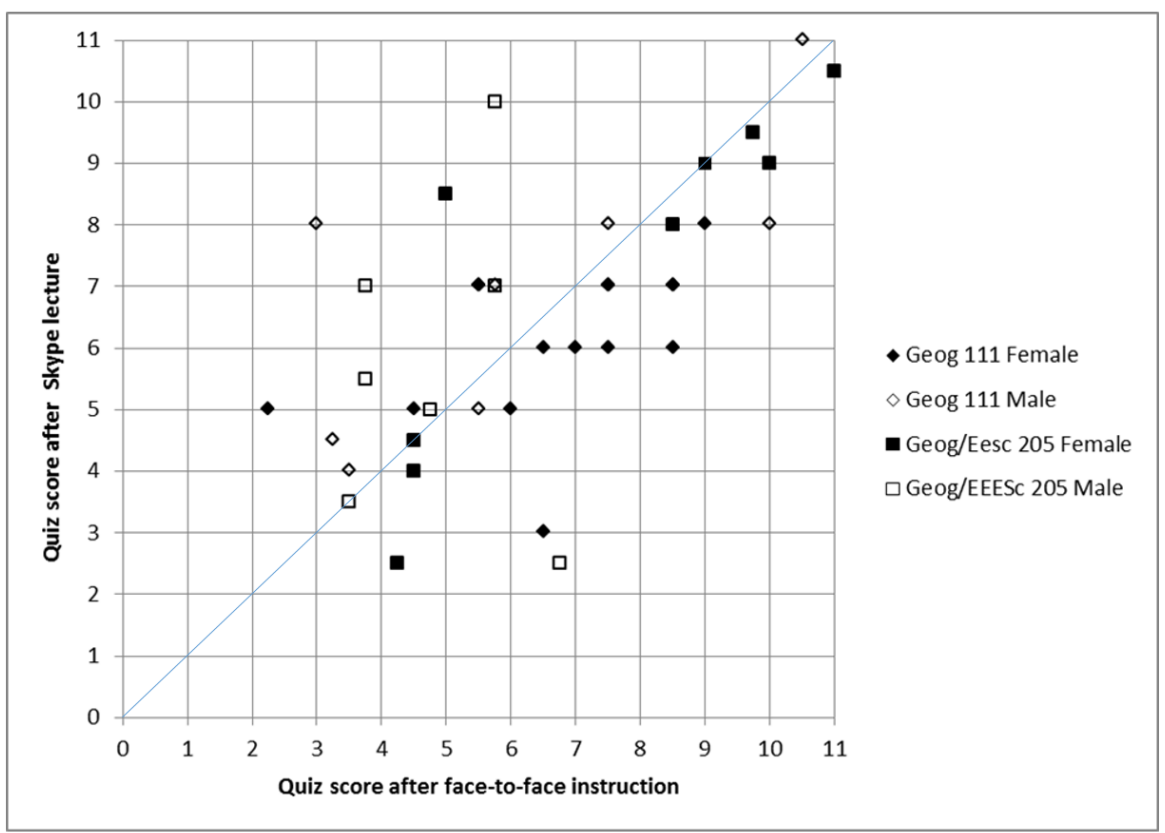

Figure 2: Relationship between face-to-face and post-Skype test scores, by student, gender and course. The Skype test score is based on a test following the week of teaching by web-based conferencing, and the face-to-face test scores are based on the average test scores after the preceding and subsequent weeks. The straight line is a line of unit slope based on concordance of test scores between teaching face-to-face and via Skype. Most female students (shown as solid symbols) have scores below the line, i.e. they did better after the face-to-face lectures than after the web-based conferencing (Skype). Most male students (hollow symbols) have scores above the line, which indicates that they scored better following Skype than after face-to-face lectures. There are fewer data points in the graph than in table 2, because the figure above requires the students to have been present for three consecutive tests.

A comparison with other years was also undertaken with respect to quizzes in the introductory physical geography course on weather and climate. This course had few changes from the previous and subsequent semesters. On a cohort-to-cohort basis it was, therefore, possible to compare results of a similar test on the same subject matter taught under face-to-face teaching and learning and web-based conferencing. The average score after the Skype lecture was 6.58/10, and after face-to-face instruction in previous and subsequent years was 5.77/10. This difference was greater than for the same class in previous and subsequent tests, but was not statistically significant. The greater difference is possibly due to a cohort effect, but may also be caused by slight differences in teaching from year to year. It could equally be an artifact of sample size and statistical variability, since the difference is still not statistically significant.

Finally, the comparison between answers to multiple-choice questions in the winter 2012 sections of Geography 111 and 121, and previous and subsequent sections was evaluated with a chi square test of goodness-of-fit. There was no significant difference in four of five questions evaluated. The number of available questions in Geography 121 
was limited by the small number of students and the need for at least five students in the correct and incorrect categories to make the chi square test valid.

\section{DISCUSSION}

\section{The efficacy of web-based conferencing as a teaching and learning medium}

It is widely reported that there is "no significant difference" between different teaching technologies (e.g. Abdous and Yoshimura, 2010; Arbaugh et al., 2009; Means et al., 2010; Russell, 2000). This conclusion is not universally accepted because it is impossible to control all potentially relevant variables (e.g. Joy and Garcia, 2000; Kirkwood and Price, 2013).

The evidence from both the weekly quizzes and the final examination questions presented here shows that overall student learning was unaffected by the teaching and learning medium in the short term of a week. However, it is possible that different results would have been obtained under different circumstances. Students clearly saw the need for web-based conferencing when they understood my situation. In the weeks following the web-based conferencing, students informally asked me about the personal situation that caused my need for absence. The students conveyed compassion and understanding, and may have been much more forgiving than in an unnecessary situation such as absence to attend a professional development event.

\section{Gender differences}

Although there was no statistically significant change in student learning between the two approaches, there are suggestions of a difference between male and female responses to teaching through web-based conferencing. The majority of male students did slightly better on tests after the Skype lectures than they did in tests after face-to-face lectures. Female students were also more ambivalent about the experience of Skype lectures. This finding is apparently new, but the relatively low number of students means that more research is needed before any firm conclusions can be drawn.

\section{Importance of the professor}

The issue of physical discomfort raised by students came as a surprise, since faceto-face lectures usually involve PowerPoint slides projected onto the same screen. However, on reflection, student attention is not directed at the screen all of the time during face-to-face lectures. They look at the professor for much of the class. This focus on the professor in face-to-face instruction manifested itself in comments about the lack of body movement in the Skype lectures. Comments about missing the professor in class, concern about the situation that caused the professor to stay at home, and appreciation of the fact that a substitute instructor wasn't the best option demonstrated a personal connection with the professor. A previous study found that students from minority backgrounds particularly value learner-instructor interactions (Ke and Kwak, 2013), and it is likley that students in a community college environment value these connections more. Even in a medical school, an increase in face-to-face teaching has been associated with an increase in student satisfaction, but not with an increase in student grades (Whillier and Lystad, 2012). The importance of the physical presence of the professor in class may be associ- 
ated with the issue of personal presence in online courses (Bair and Bair, 2011; Kear et al., 2012; Reupert et al., 2009). Presence can be established in an exclusively online course, but the approaches may be different than in face-to-face courses (Bair and Bair, 2011).

\section{Importance of prior student experience}

Many of the student comments (positive, negative and ambivalent) made unsolicited comparisons between the web-based conferencing and the regular face-to-face lectures. Thus, student experience and impressions of face-to-face lectures are likely to be important in any evaluation of alternative modes of delivery. Students with good experiences of face-to-face instruction are likely to be less appreciative and less open to alternative modes of delivery than students who have had poor previous experiences of face-to-face instruction. Previous studies of the efficacy of technology have not taken prior student experiences into account and this may be a worthwhile subject for future research.

\section{Exposure to alternative modes of course delivery}

None of the student comments made reference to previous experiences of web-based conferencing or similar technologies. Students were not systematically asked whether they had experienced anything like this before, but informal conversations with students suggest this was a first for most students. It is possible this experience may have encouraged students to explore alternative modes of delivery, but this would require a longitudinal survey that was not feasible in the present study. The effect of limited exposure to web-based conferencing and similar technologies on subsequent enrollment in web-based courses has not been investigated in previous studies. Future investigation would be informative.

\section{Implications of the study for academic continuity planning under more serious conditions}

The work reported here relates to a minor disruption to academic continuity, but it also provides an opportunity to discuss the challenges associated with implementation of web-based conferencing under conditions of more serious disruption. Although internet services are likely to be disrupted during a natural disaster, newer technologies potentially enable the internet to be restored with drones and balloons. These same technologies are currently proposed for the offering of MOOCs in Africa (e.g. http://www.irex.org/news / can-moocs-have-impact-africa), and could potentially enable web-based conferencing after a catastrophic event, even if traditional cable services were unavailable or restricted.

Successful adoption of online technologies requires time, planning, and knowledge on the part of the instructor (De Gagne and Walters, 2009; Kear et al., 2012), and even under normal circumstances many instructors feel inadequately supported by their institution (Ocack, 2011). The complexities of multitasking and improvisation in an online environment (Kear et al., 2012), pose challenges, to the extent that some instructors have been challenged by the need to appropriately manage their emotions (Regan et al., 2012). The stress of emergency situations may make this issue of even greater concern. I would hazard to guess that many colleges and universities are ill-equipped to offer extensive support in emergency conditions. The isolated nature of my situation made it possible for the Educational Technology Coordinator to assist, but that assistance would have been unsustainable if large numbers of professors would have requested assistance. Faculty support and dialogue in a community of practice would be important. 
The importance of interpersonal relations between educational technical support and faculty cannot be overstated. The excellent rapport between myself and the Educational Technology Advisor made everything possible. Such relationships are not built instantaneously, but must be nurtured and developed over time. Indeed, the importance of interpersonal relations extends beyond the educational technology or IT department to include the students. The use of Skype enabled learning to continue under less than perfect circumstances, but academic continuity was only achieved because of the willingness of the students to participate on this basis.

\section{Reflections on the use of technology for teaching and learning and advice to instructors faced with class cancellation}

I learned that educational technology provides a viable alternative to face-to-face instruction. However, student response was not uniformly enthusiastic. This is unsurprising, bearing in mind the diversity of backgrounds and abilities in contemporary college classrooms. It is clear that this phenomenon and the reasons behind it are under-reported in the literature. One study showed that differences in learning styles were identified when video-linked tutorials were used, but were less apparent in the classroom (Jones et al., 2010). Another study showed that students with lower course grades benefited more from online videos than did students with higher grades (Dupuis et al., 2013). Generalizations about the effectiveness of different educational technologies are problematic.

I continue to have concerns about the robustness of available teaching and learning technologies, but assume that those issues will be eventually overcome. Despite the limitations, my confidence in educational technology increased with this experience.

Short-term changes in course delivery provide the professor and students with new experiences and information, and an opportunity to reflect on the nature of teaching and learning. The learning for me was the importance of appreciating diversity of student learning styles and willingness to adapt to new technologies. Together with the knowledge that I'd done my best for both my family and students under difficult circumstances, that has been ample reward for a modest output of effort.

\section{CONCLUSION}

Web-based conferencing by Skype is a viable form of alternative course delivery under emergency situations. Despite being organized at short notice, overall learning was unimpeded by web-based conferencing from home for a one-week period. However, there were small gender effects, with female students scoring lower after web-based conferencing than after face-to face instruction. In contrast, males scored higher after web-based conferencing than after face-to-face instruction. There is a need for additional work on gender effects associated with web-based learning.

In general, there was reduced student engagement, and it is unknown how long even that reduced level of student engagement could have been maintained. None of the technical issues was insurmountable, although they did require professional attention.

The level of educational technology support required to make synchronous webbased conferencing work for the novice is daunting. In the context of academic continuity planning there is a need for appropriate and timely training opportunities and a reward system that encourages faculty participation in that training. Successful implementation 
of an academic continuity plan requires the encouragement of strong and collegial interpersonal relations. These relations fuel willingness to confront and overcome the challenges of working in a difficult environment. Nothing can happen without goodwill and commitment on the part of faculty, students, and the people around them.

\section{ACKNOWLEDGEMENTS}

My thanks to Mike Minions Ed Tech Coordinator at Okanagan College for technical assistance and comments on an earlier draft, and to Marie Molloy for comments and suggestions. The paper has also benefited from the comments of editor Gary Poole and anonymous reviewers.

Terence Day is a Professor in the Department of Geography, Earth and Environmental Science at Okanagan College (Canada).

\section{REFERENCES}

Abdous, M., \& Yoshimura, M. (2010). Learner outcomes and satisfaction; A comparison of live video-streamed instruction, satellite broadcast instruction, and face-to-face instruction. Computers \& Education, 55, 733-741.

Arbaugh, J.B., Godfrey, M.R., Johnson, M., Pollack, B.L., Niendorf, B., \& Wresch, W. (2009). Research in online and blended learning in the business disciplines: key findings and possible future directions. The Internet and Higher Education, 12, 71-87.

Bair, B.E., \& Bair, M.A. (2011). Paradoxes of online teaching. International Journal for the Scholarship of Teaching and Learning, 5, (2).

Brouwer, N. \& McDonnell, C. (2009). Online Support and Online Assessment for Teaching and Learning Chemistry. In Eilks, I. \&Byers, B. (Eds.), Innovative methods of teaching and learning Chemistry in Higher Education (pp. 123-152) Cambridge, UK: RSC Publishing.

Buultjens, M., \& Robinson, P. (2011). Enhancing aspects of the higher education student experience. Journal of Higher Education Policy and Management, 33(4), 337-346.

De Gagne, J.C., \&Walters, K. (2009). Online teaching experience: A qualitative metasynthesis (QMS). MERLOT Journal of Online Learning and Teaching, 5, 577-589.

Douglas, C. (2011). Preparing for the unexpected: Ensuring academic continuity. Desire2Learn Whitepaper. http://www.desire2learn.com/resources/library/docs/wp/Desire2Learn _whitepaper_Academic_Continuity.pdf

Dupuis, J., Coutu, J., \& Laneuville, O. (2013). Application of linear mixed-effect models for the analysis of exam scores: online video associated with higher scores for undergraduate students with lower grades. Computers \& Education, 66, 64-73.

Foster, A.L., \& Young, J.R. (2005). The Internet as emergency tool. The Chronicle of Higher Education, September 16. Retrieved from http://chronicle.com/article/The-Internet-as -Emergency-Tool/15881.

Holmes, E.C., Ghedin, E., Halpin, R.A., Stockwell, T.B., Zhang, X.Q., Fleming, R., Davey, R., Benson, C.A., Mehta, S., Taplitz, R., Liu, Y.T., Brouwer, K.C., Wentworth, D.E., Lin, X. Schooley, R. T. (2011). Extensive geographical mixing of 2009 human H1N1 influenza: A virus in a single university community. Journal of Virology, 85(14), 6923-6929. 
Jones, A.Y.M., Dean, E., \& Hui-Chan, C. (2010). Comparison of teaching and learning outcomes between video-linked, web-based, and classroom tutorials: An innovative international study of profession education in physical therapy. Computers \& Education, 54, 1193-1201.

Joy, E.H., \& Garcia, F.E. (2000). Measuring learning effectiveness: a new look at no-significantdifference findings. Journal of Asynchronous Learning Networks, 4, 33-39.

Ke, F., \& Kwak, D. (2013). Online learning across ethnicity and age: A study on learning interaction participation, perception, and learning satisfaction. Computers \& Education, 61, 43-51.

Kear, K., Chetwynd, F., Williams, J., \& Donelan, H. (2012). Web conferencing for synchronous online tutorials: Perspectives of tutors using a new medium. Computers \& Education, 58, 953-963.

Kirkwood, A., \& Price, L. (2013). Examining some assumptions and limitations of research on the effects of emerging technologies for teaching and learning in higher education. British Journal of Educational Technology, 44, 536-543.

Leonard, E. W. (2009). Teaching Sicko. Journal of Law, Medicine and Ethics, 37, 139-146.

Lu, X.A.L., \& Ramsey, M.C. (2013). Passive Addiction or Why We Hate Work: An Investigation of Problems in Organizational Communication. Lanham, MD: University Press of America.

McKimm, J. (2009). "Teaching Quality, Standards and Assessment." In H. Fry, Ketteridge, S., \& Marshall, S. (Eds.), Teaching and Learning in Higher Education (pp. 186-197). London, Routledge.

Means, B., Toyama, Y., Murphy, R., Bakia, M., \& Jones, K. (2010). Evaluation of evidence-based practices in on-line learning: a meta-analysis and review of online learning studies. Washington, DC: US Department of Education Office of Planning, Evaluation, and Policy Development. http://www2.ed.gov/rschstat/eval/tech/evidence-based-practices/finalreport.pdf

Meyer, K.A., \& Wilson, J.L., (2011). The Role of Online Learning in the Emergency Plans of Flagship Institutions. Online Journal of Distance Learning Administration, Volume IV, Number I, Spring 2011 http://www.westga.edu/ distance/ojdla/spring141/meyer_wilson141.html

Nielsen, G.B. (2011). Peopling policy: On conflicting subjectivities of fee-paying students. In C. Shore, S. Wright and D. Però (Eds.), Policy Worlds: Anthropology and the Analysis of Contemporary Power. (pp. 68-85). Oxford: Berghahn,

Ocak, M.A. (2011). Why are faculty members not teaching blended courses? Insights from faculty members. Computers \& Education, 56, 689-699.

Omar, A., Liu, L.C., \& Koong, K.S. (2008). From disaster recovery to mobile learning: A case study. International Journal of Mobile Learning and Organisation, 2(1), 4-7.

Quesada-Pineda, H.J., Adams, E., \& Hammett, A.L. (2011). Incorporating experiential teaching methods in sustainable natural resources curriculum: A case study. Journal of Natural Resources \& Life Sciences Education, 40(1), 181-190.

Regan, K., Evmenova, A., Baker, P., Jerome, M.K., Spencer, V., Lawson, H., \& Werner, T. (2012). Experiences of instructors in online learning environments: Identifying and regulating emotions. Internet and Higher Education, 15, 204-212. 
Reupert, A., Maybery, D., Patrick, K. \& Chittleborough, P. (2009). The importance of being human: Instructors' personal presence in distance programs. International Journal of Teaching and Learning in Higher Education, 21(1), 47-56.

Russell, T.L. (2000). The no significant difference phenomenon: a comparative research annotated bibliography on technology for distance education. Raleigh, NC: North Carolina State University.

Santibañez, S., Fiore, A.E., Merlin, T.L., \& Redd, S. (2009). A primer on strategies for prevention and control of seasonal and pandemic influenza. American Journal of Public Health, 99(S2), S216-S224.

SchWeber, C. (2008). Determined to learn: Accessing education despite life-threatening disasters. Journal of Asynchronous Learning Networks, 12(1) 37-43.

SchWeber, C. (2013). Survival Lessons: Academic Continuity, Business Continuity, and Technology. In Van den Bossche, P, Gijselaers, WH., Milter, RG. (Eds.) Facilitating Learning in the 21st Century: Leading through Technology, Diversity and Authenticity (pp. 151- 163). Dordrecht: Springer.

University of British Columbia (n.d.) Time to ACT (Academic Continuity Toolkit) http://act .elearning.ubc.ca/

University of Washington School of Law (n.d.) H1N1 Academic Continuity Plan. https://www .law.washington.edu/students/academics/Flu.aspx

Van, D., McLaws, M-L., Crimmins J., Maclntyre, C.R., Seale, H. (2010). University life and pandemic influenza: Attitudes and intended behaviour of staff and students towards pandemic (H1N1) 2009. BMC Public Health, 10, 130.

Virginia Tech (n.d.) Academic continuity: Strategies for alternative instructional delivery. http://www.iddl.vt.edu/acplan/

Whillier, S., \& Lystad, R.P. (2012). The effect of face-to-face teaching on student knowledge and satisfaction in an undergraduate neuroanatomy course. Anatomical Science Education, 6(4) 239-245.

Young, J.R. (2009). In Case of Emergency, Break Tradition-Teach Online. The Chronicle of Higher Education, August 17. Retrieved from http://cwuonlinetf.pbworks.com/f/ln+Case +of+Emergency.pdf 